\title{
Utilization of Different Microbes in Bioremediation of Hydrocarbon Contaminated Soils Stimulated With Inorganic and Organic Fertilizers
}

\author{
John Kanayochukwu Nduka*, Linda Nkechi Umeh, Isaac Obi Okerulu, Lilian Ngozi Umedum and Helen Nkechi Okoye
}

Environmental Chemistry and Toxicology Research Unit, Pure \& Industrial Chemistry Department, Nnamdi Azikiwe University, P.M.B. 5025, Awka, Anambra State, Nigeria

\begin{abstract}
Different microbes (E.coli, Proteus, Klebsiella and Pseudomonas $s p$ ) were utilized in degradation of different hydrocarbon (Engine oil/diesel, kerosene and fuel) contaminated soils amended with inorganic (NPK and urea) and organic (cow dung and poultry litter) fertilizers and in some their combination. The incubation period ranged from $3-18$ days. Bacterial population count and residual hydrocarbon were determined .Results showed that bacterial population count increased as the microbes utilized hydrocarbon for carbon and energy sources, the increase in population count and degradation of the hydrocarbons was stimulated by the fertilizer. It was also observed that as the population count increased due to hydrocarbon utilization for carbon and energy, residual hydrocarbon decreased and percentage degradation increased. Urea fertilizer was the best amendment for E.coli to degrade kerosene, NPK and cow dung differently aided the same E.coli in degrading engine oil. Pseudomonas and Proteus species degraded kerosene and fuel better in the presence of NPK fertilizer. Klebsiella specie degraded diesel and engine oil better when amended with poultry litter and cow dung respectively at least for the first 9 days. More than $90 \%$ of the hydrocarbons were degraded within each incubation period. The microbes began to die as from the $15^{\text {th }}$ day of incubation, this may be due to secretion of toxic secondary metabolites. Control experiments revealed that there was initial increase in population count of the microbes as they utilized the hydrocarbon for carbon and energy, but they began to die because of non-stimulation with fertilizer, therefore less than $50 \%$ of the hydrocarbons were degraded in all the control experiments. Maize seeds grew on the remediated soil within six (6) days of planting.
\end{abstract}

Keywords: Biodegradation; Bioremediation; Microbes; Hydrocarbon; Fertilizer; Contaminated soil

\section{Introduction}

The world, in which we live as it is today, is the world in which everything we do as regards human growth, biological, physical, economic, industrial and infrastructural growth, science and technological growth etc. revolves around energy. Apart from the traditional firewood, wind and hydro power, petroleum hydrocarbon continues to be used as the most principal and versatile source of energy and therefore an important global environmental pollutant [1]. Crude oil or petroleum hydrocarbon exploration and exploitation which came after industrial revolution stems from advances in science and technology which have enabled humans to exploit their natural resources, although not without a cost, as it has generated unprecedented disturbances in global elemental cycles [2]. The relatively sudden introduction of xenobiotic chemicals as well as the massive relocation of natural materials to different environmental compartments can often overwhelm the self cleaning capacity of recipient ecosystems and therefore result in the accumulation of pollutants to problematic or even harmful levels [3]. Bioremediation plays a great role in solving some of these problems. Bioremediation is the application of biological treatment to clean up hazardous chemicals. This process involves detoxification where the pollutant may be converted to less toxic substances and mineralization, where the waste material can be converted into inorganic compounds such as carbon dioxide, water, methane and sometimes fatty acids [4]. Bioremediation is not new to human race but new approaches that stem from advances in molecular biology and process engineering are emerging. Microbes bioremediate the environment as they biodegrade the pollutant to obtain carbon and energy, Biodegradation specifically refers to chemical breakdown or mineralization of materials facilitated by biological organisms or products [5]. Contamination of the environment with petroleum hydrocarbons has caused critical health defects and therefore increasing attention has been focused on developing and implementing innovative technology for cleaning up this contamination $[3,6]$. When oil spillages occur as with the cases in the Niger-delta region of Nigeria , concerted efforts are made to remove, remediate or recover the spilled oil immediately, but when the spill is small as in automobile workshops, gasoline petrol station, and during tanker, loading or off-loading operations at the refinery or during clean-up operations, the possible effect is that it may be ignored, but on continuous and prolonged spill as the case has been, contamination of ground water and air due to evaporation is possible because of its persistence. Bioremediation methods therefore come in handy and have correctly received favorable publicity as promising environmentally friendly technique for the remediation of hydrocarbon contaminated ecosystem [7]. This is possible because microorganisms have enzyme system to degrade and utilize different hydrocarbon as a source of carbon and energy [8]. A number of gram positive and negative microbes have been reported to be capable of utilizing a wide variety of hydrocarbons as carbon and energy [9]. The microorganisms include bacteria of the genera Klebsiella, Proteus, Bacillus, Escherichia, Pseudomonas, Streptomyces, Nocardia, Seratia, Xanthomonas, Micrococcus etc. and

*Corresponding author: John Kanayochukwu Nduka, Environmental Chemistry and Toxicology Research Unit, Pure \& Industrial Chemistry Department, Nnamdi Azikiwe University, P.M.B. 5025, Awka, Anambra State, Nigeria, E-mail johnnduka2000@yahoo.co.uk

Received December 17, 2011; Accepted February 20, 2012; Published February 22, 2012

Citation: Nduka JK, Umeh LN, Okerulu IO, Umedum LN, Okoye HN (2012) Utilization of Different Microbes in Bioremediation of Hydrocarbon Contaminated Soils Stimulated With Inorganic and Organic Fertilizers. J Pet Environ Biotechnol 3:116. doi:10.4172/2157-7463.1000116

Copyright: @ 2012 Nduka JK, et al. This is an open-access article distributed unde the terms of the Creative Commons Attribution License, which permits unrestricted use, distribution, and reproduction in any medium, provided the original author and source are credited. 
Citation: Nduka JK, Umeh LN, Okerulu IO, Umedum LN, Okoye HN (2012) Utilization of Different Microbes in Bioremediation of Hydrocarbon Contaminated Soils Stimulated With Inorganic and Organic Fertilizers. J Pet Environ Biotechnol 3:116. doi:10.4172/2157-7463.1000116

Page 2 of 9

fungi of the genera-Rhizopus, Fusarium, Pencillium, Cladosporium and Aspergillus etc [10]. The hydrocarbon degrading microbes have an inherent capacity to assimilate hydrocarbons and/or its products [11]. The process is therefore regarded as a complex biological oxidation process involving mostly aerobic organisms which may be enhanced by supplementation with fixed nitrogen, phosphate and other nutrients [12]. Ngobiri et al. [13] reported that native microbes caused reduction of total petroleum hydrocarbon (TPH) by $25 \%$ within the first three weeks, following the application of N:P:K,15:15:15 fertilizer as major source of macro-nutrient in a study to reclaim crude oil contaminated site at Igwuritta area of Rivers state, Nigeria. The use of composting in bioremediation has received little attention [14] in spite of the fact that composts have been reported to have potential for remediation of heavily contaminated sites $[15,16]$. Previous composting experiments employing hydrocarbon contaminated soil co-composted with cow manure and mixed vegetable wastes showed that more than $90 \%$ of the hydrocarbons were removed [17]. Nitrogen component of sewage sludge has also been utilized as nutrient for microbes in bioremediation of hydrocarbon-contaminated soil inoculated with organic manure, at the end of the incubation period, total petroleum hydrocarbon in the control decreased by $17 \%$ while that of the experiment decreased by $99.8 \%$.The organism growing on the nutrients present in the compost system readily metabolized the contaminant hydrocarbons in the compost mixture while still growing on the sludge [18 ].Apart from cow dung, sewage sludge, poultry manure as organic fertilizer in contaminated soil was reported have increased microbial growth and biodegradation was found to be enhanced by poultry manure [19]. Also co-composting hydrocarbon-contaminated soil with poultry manure showed that poly aromatic hydrocarbons (PAHs) could be removed from the soil by composting [20]. The objective of this work is to ascertain the effectiveness of various microbes used in degradation of different hydrocarbon contaminated soil amended with inorganic or organic fertilizer when used singly or in combination and also to compare the bacterial population count when using inorganic with organic as well as when both are combined.

\section{Materials and Methods}

\section{Hydrocarbon}

The hydrocarbons used in all the experiment were collected from Port-Harcourt refinery.

\section{Soil sample}

The soil sample was obtained from a site free from any hydrocarbon contamination, about $200 \mathrm{~m}$ away from chemistry laboratory of Nnamdi Azikiwie University, Awka. Soil sample was collected by hand digging to a depth of $30 \mathrm{~cm}$, it was mixed thoroughly sieved through screens with $2 \mathrm{~mm}$ diameter openings to remove stones, wood particles and other debris and stored in a sterile polyethylene flask (2-liter capacity) at $10^{\circ} \mathrm{C}$ so as to reduce moisture losses [21] ,after proper sterilization. Laboratory analysis revealed that the soil was sandy loamy type of soil. The water holding capacity was evaluated as suggested by Watwood and White [22]. The mineral salts, organic and inorganic fertilizers were all sterilized.

\section{Microorganism}

The bacterial cultures utilized in this study were Escherichia coli, Proteus, Pseudomonas and Klebsiella species obtained from Nnamdi
Azikiwe University Teaching Hospital Nnewi and Glanson Medical Laboratory, Awka. The composition of the mineral salts medium used contain $0.29 \mathrm{~g} \mathrm{KCl}, 10 \mathrm{~g} \mathrm{NaCl}, 0.42 \mathrm{~g} \mathrm{MgSO}_{4} .7 \mathrm{H}_{2} 0,0.83 \mathrm{~g} \mathrm{KH}_{2} \mathrm{PO}_{4}$, $0.42 \mathrm{~g} \mathrm{NaNO}_{3}$ and de-ionized water. The prepared medium was transferred into six (6) $250 \mathrm{ml}$ conical flasks and autoclaved at $121^{\circ} \mathrm{C}$ for 15 minutes. The hydrocarbon was also sterilized separately in a tight screw-capped bottle at same temperature and time. Also sterilized were 144 empty bottles and organic and inorganic fertilizers, screen test for hydrocarbon utilization was determined by the method of Okpokwasili and Okorie (1998) [23]. Pour plate method in which nutrient agar(oxide) was autoclaved and allowed to cool at $45^{\circ} \mathrm{C}, 0.01$ $\mathrm{ml}$ of each organism was added into each separate sterile Petri dish. The medium was poured into the Petri dish and swirled properly, then was allowed to gel .It was incubated at $30^{\circ} \mathrm{C}$ and the counts were taken after every $72 \mathrm{hrs}$. CFU/ml of each $0.4 \mathrm{ml}$ stock solution were as follows: E.coli $\left(1.1 \times 10^{8}\right)$, Pseudomonas $\left(0.8 \times 10^{8}\right)$, Proteus $\left(0.9 \times 10^{8}\right)$ and Klebsiella $\left(1.0 \times 10^{8}\right)$.

In all six (6) composite experiments were performed as follows:

1. Biodegradation of kerosene contaminated soil using Escherichia coli $s p$ amended with inorganic fertilizer (NPK and Urea) (Figure 1a \& 1b). Four tests were carried out as;

i. Sample A $=0.4 \mathrm{ml}$ stock solution of Escherichia coli, $10 \mathrm{~g}$ of soil, $1 \mathrm{ml}$ of kerosene, $50 \mathrm{ml}$ of mineral salts medium and $1 \mathrm{~g}$ of NPK.

ii. Sample B $=0.4 \mathrm{ml}$ stock solution of E.coli, $10 \mathrm{~g}$ of soil, $1 \mathrm{ml}$ of kerosene, $50 \mathrm{ml}$ of mineral salts medium and $1 \mathrm{~g}$ of Urea.

iii. Sample C $=0.4 \mathrm{ml}$ stock solution of E.coli, $10 \mathrm{~g}$ of soil, $1 \mathrm{ml}$ of kerosene, $50 \mathrm{ml}$ mineral salt, $0.5 \mathrm{~g}$ each of NPK and Urea.

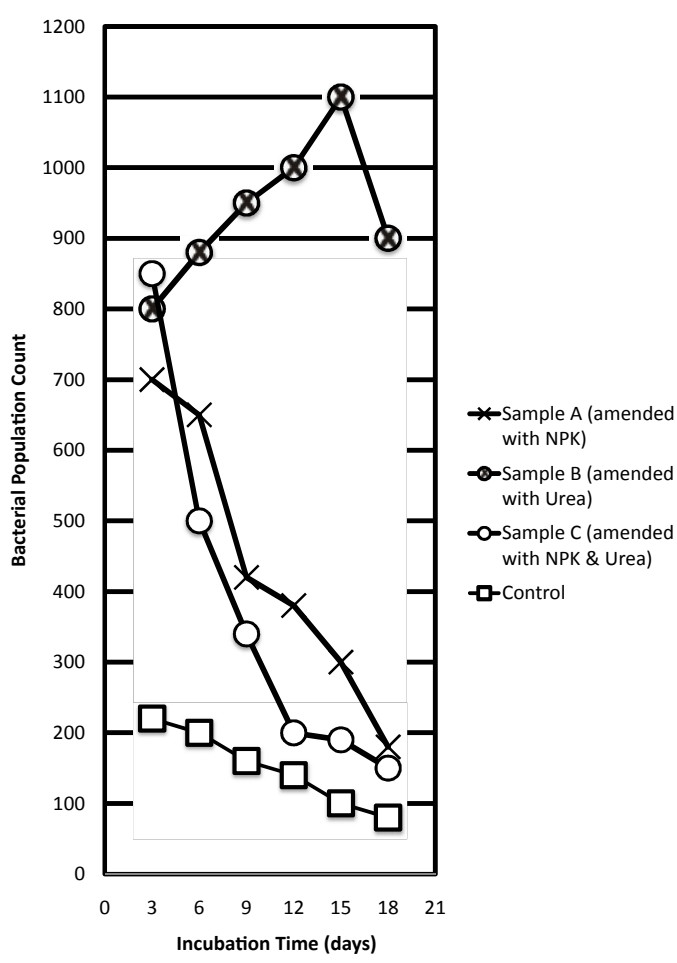

Figure 1a: Bioremediation of kerosene contaminated soil using E.Coli amended with inorganic fertilizer (Poultry litter and Cow dung). 
Citation: Nduka JK, Umeh LN, Okerulu IO, Umedum LN, Okoye HN (2012) Utilization of Different Microbes in Bioremediation of Hydrocarbon Contaminated Soils Stimulated With Inorganic and Organic Fertilizers. J Pet Environ Biotechnol 3:116. doi:10.4172/2157-7463.1000116

iv. Sample D (control): $0.4 \mathrm{ml}$ stock solution of E.coli, $10 \mathrm{~g}$ of soil, $1 \mathrm{ml}$ of kerosene, $50 \mathrm{ml}$ mineral salts.

2. Biodegradation of Engine oil contaminated soil using E.coli

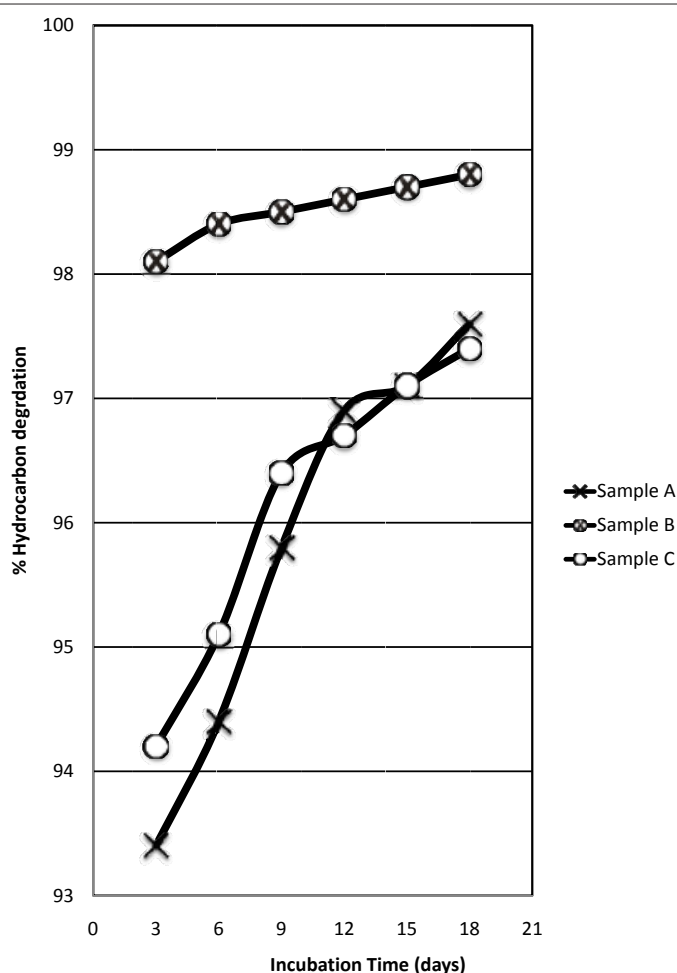

Figure 1b: \% degradation of kerosene using E.Coli when amended with inorganic fertilizers (NPK \& Urea).

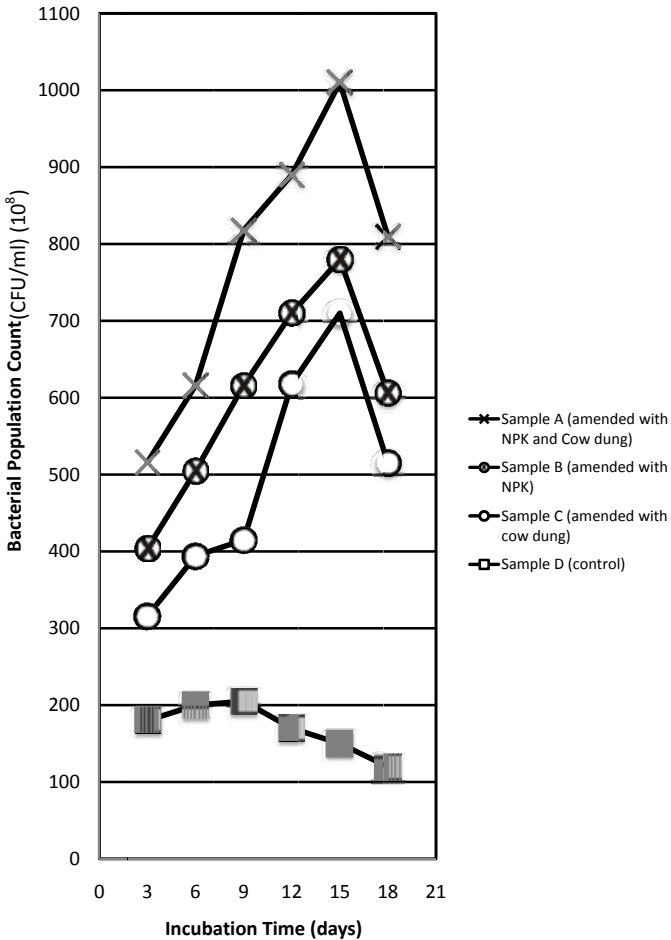

Figure 2a: Using E. coli, biomediation of Engine oil contaminated soil amended with NPK and Cow dung.

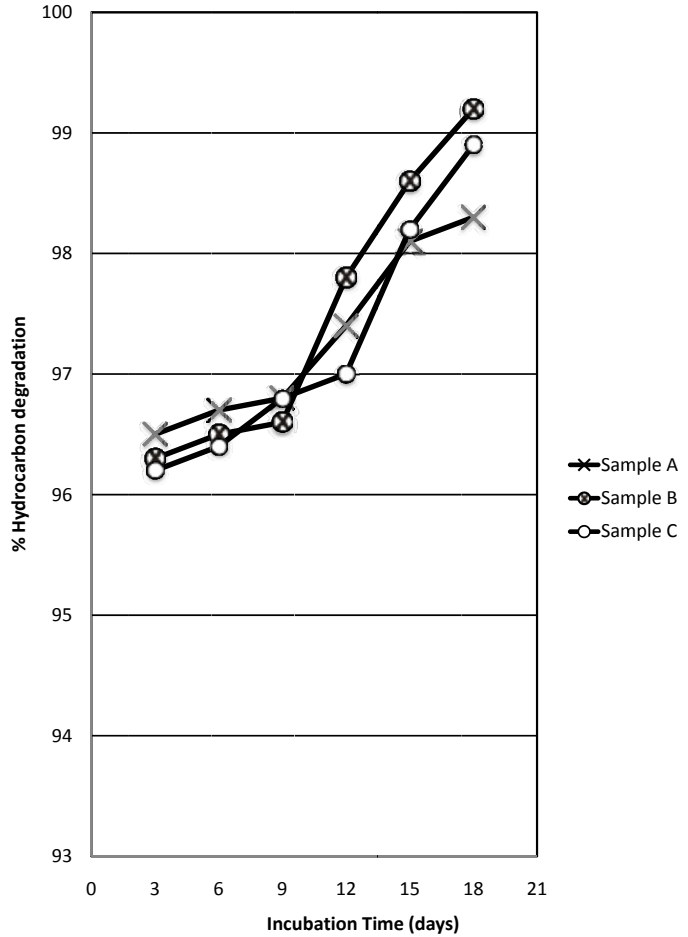

Figure 2b: \% Degradation of Engine Oil using E.Coli amended with NPK and Cow dung.

amended with NPK and cow dung. (Figure $2 \mathrm{a} \& 2 \mathrm{~b}$ ). This consists of four (4) tests as;

i. Sample A: $0.4 \mathrm{ml}$ stock solution of E. coli, $10 \mathrm{~g}$ of soil, $1 \mathrm{ml}$ engine soil, $50 \mathrm{ml}$ of mineral salts medium and $0.5 \mathrm{~g}$ each of NPK and cow dung

ii. Sample B: $0.4 \mathrm{ml}$ stock solution of E.coli, $10 \mathrm{~g}$ of soil sample, $1 \mathrm{ml}$ of engine oil, $1 \mathrm{~g}$ of NPK

iii. Sample C: $0.4 \mathrm{ml}$ stock solution of E.coli, $10 \mathrm{~g}$ of soil sample, $1 \mathrm{ml}$ of engine oil, $50 \mathrm{ml}$ mineral salt, $1 \mathrm{~g}$ cow dung.

iv. Sample D (control): as above but did not contain NPK or cow dung.

3. Biodegradation of Kerosene contaminated soil using Pseudomonas sp amended with inorganic fertilizer (NPK and Urea) (Figure 3a \& 3b). It consists of four (4) tests as;

i. Sample A: $0.4 \mathrm{ml}$ stock solution of Pseudomonas sp., $1 \mathrm{ml}$ of kerosene, $10 \mathrm{~g}$ of soil, $50 \mathrm{ml}$ of mineral salt and $1 \mathrm{~g}$ of NPK fertilizer.

ii. Sample B: $0.4 \mathrm{ml}$ stock solution of Pseudomonas sp, $1 \mathrm{ml}$ of kerosene, $10 \mathrm{~g}$ of soil, $50 \mathrm{ml}$ mineral salt, $1 \mathrm{~g}$ of Urea.

iii. Sample $\mathrm{C}=$ as above but with $0.5 \mathrm{~g}$ each of NPK and Urea.

iv. Sample D (control): as B or A, but has no fertilizer.

4. Biodegradation of fuel (petrol) contaminated soil using Proteus $s p$ amended with inorganic fertilizer (NPK and Urea) (Figure $4 a \& 4 b)$.It consists of four (4) tests as;

i. Sample A: $0.4 \mathrm{ml}$ Proteus sp stock solution, $10 \mathrm{~g}$ soil sample, $50 \mathrm{ml}$ mineral salt, $1 \mathrm{ml}$ fuel (petrol), $1 \mathrm{~g}$ NPK fertilizer. 
Citation: Nduka JK, Umeh LN, Okerulu IO, Umedum LN, Okoye HN (2012) Utilization of Different Microbes in Bioremediation of Hydrocarbon Contaminated Soils Stimulated With Inorganic and Organic Fertilizers. J Pet Environ Biotechnol 3:116. doi:10.4172/2157-7463.1000116

Page 4 of 9

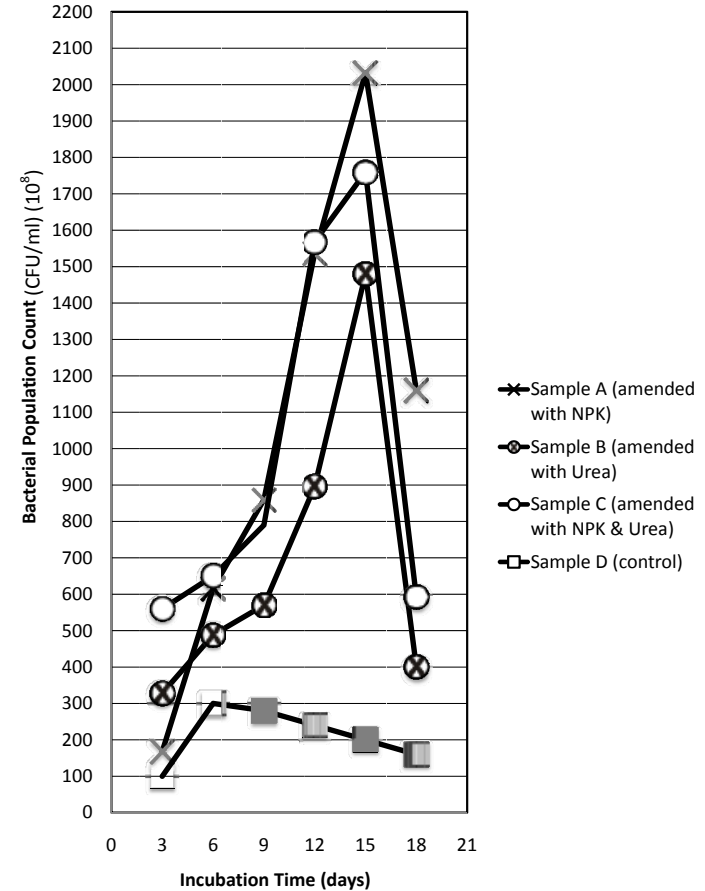

Figure 3a: Bioremediation of kerosne contaminated soil using Pseudomonas Spp amended with inorganic fertilizers (NPK and Urea).

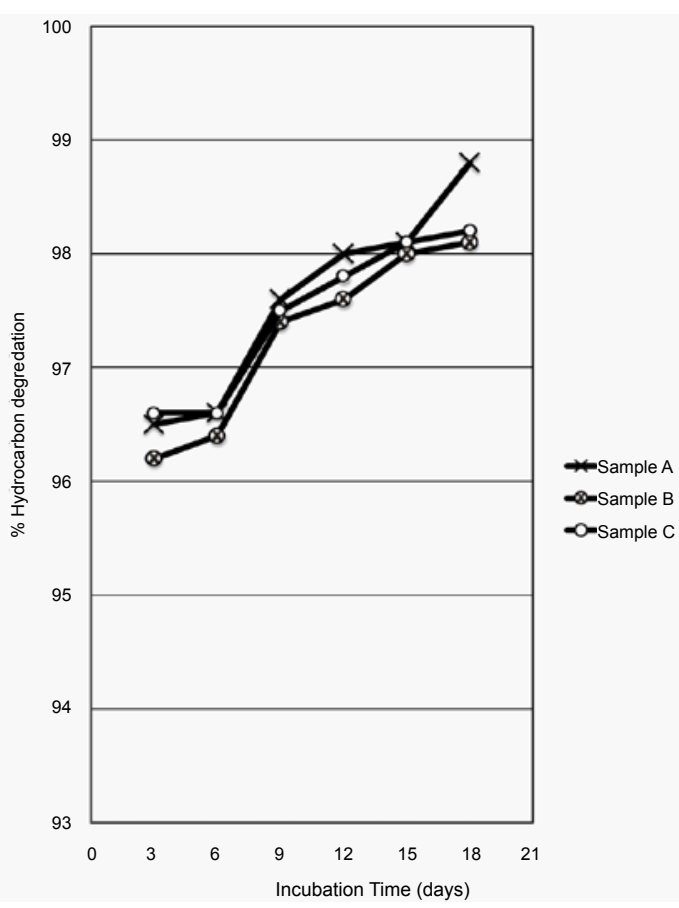

Figure 3b: \% Degradation of kerosene using Pseudomonas amended with inorganic fertilizers (NPK and Urea).

ii. Sample B: $0.4 \mathrm{ml}$ Proteus sp stock solution, $10 \mathrm{~g}$ soil sample, $50 \mathrm{ml}$ mineral salt, $1 \mathrm{ml}$ fuel (petrol), $1 \mathrm{~g}$ of Urea.

iii. Sample C: $0.4 \mathrm{ml}$ Proteus sp stock solution, $10 \mathrm{~g}$ soil sample, $50 \mathrm{ml}$ mineral salt, $1 \mathrm{ml}$ fuel (petrol) and $0.5 \mathrm{~g}$ each NPK and Urea. iv. Sample D (control): contain all but no fertilizer i.e. (no urea or NPK).

5. Biodegradation of diesel contaminated soil using Klebsiella sp

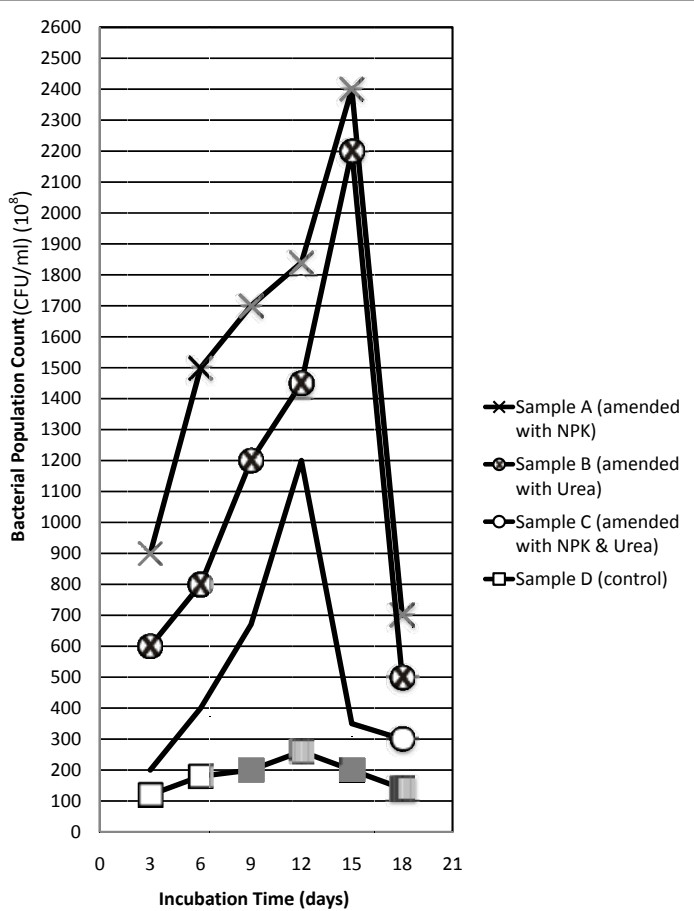

Figure 4a: Bioremediation of Fuel contaminated soil using Proteus amended with Inorganic Fertilizers (NPK and Urea).

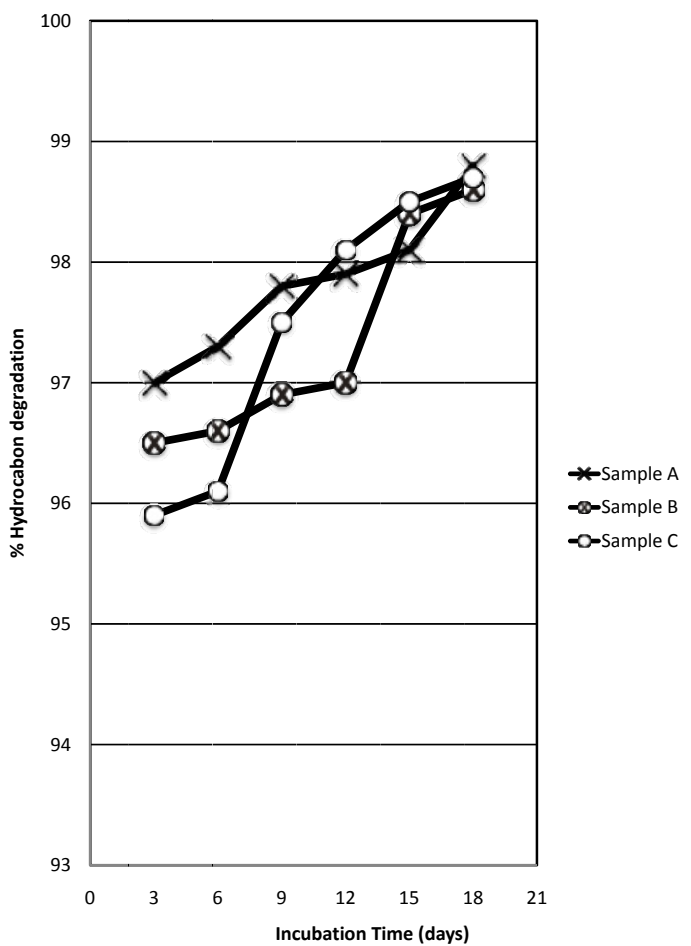

Figure 4b: \% degradation of Fuel using proteus amended with inorganic fertilizers (NPK and Urea). 
Citation: Nduka JK, Umeh LN, Okerulu IO, Umedum LN, Okoye HN (2012) Utilization of Different Microbes in Bioremediation of Hydrocarbon Contaminated Soils Stimulated With Inorganic and Organic Fertilizers. J Pet Environ Biotechnol 3:116. doi:10.4172/2157-7463.1000116

amended with cow dung and poultry litter (Figure 5a \& 5b).It consists of four (4) tests as;

i. Sample A: $0.4 \mathrm{ml}$ stock solution of Klebsiella sp, $10 \mathrm{~g}$ soil samples, $50 \mathrm{ml}$ mineral salt, $1 \mathrm{ml}$ diesel and $0.5 \mathrm{~g}$ poultry litter

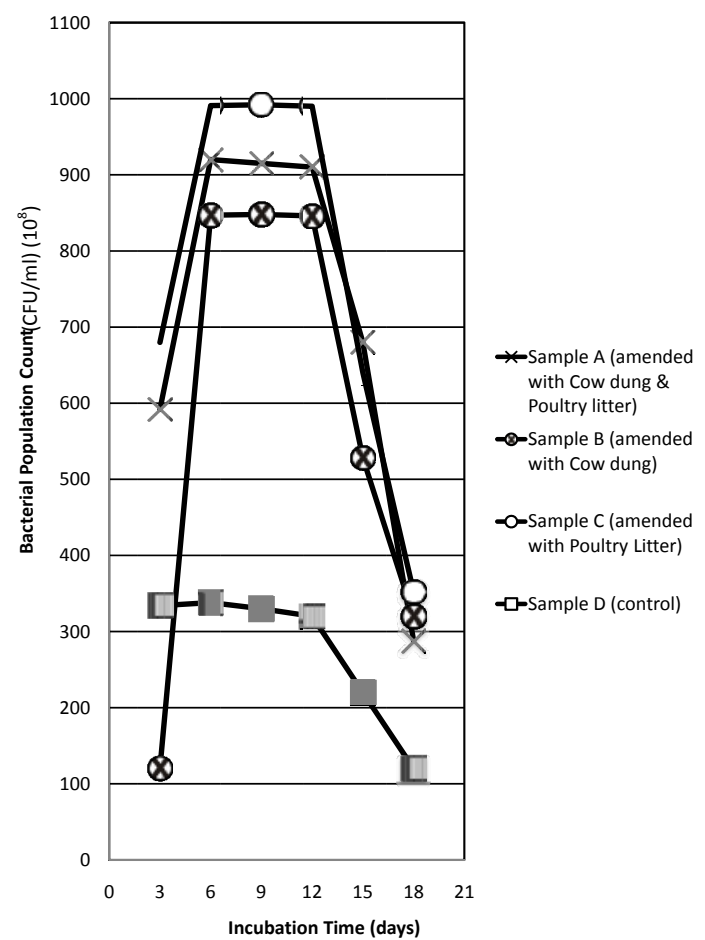

Figure 5a: Bioremediation of Diesel contaminated soil using Klebsiella amended with NPK and Cow dung.

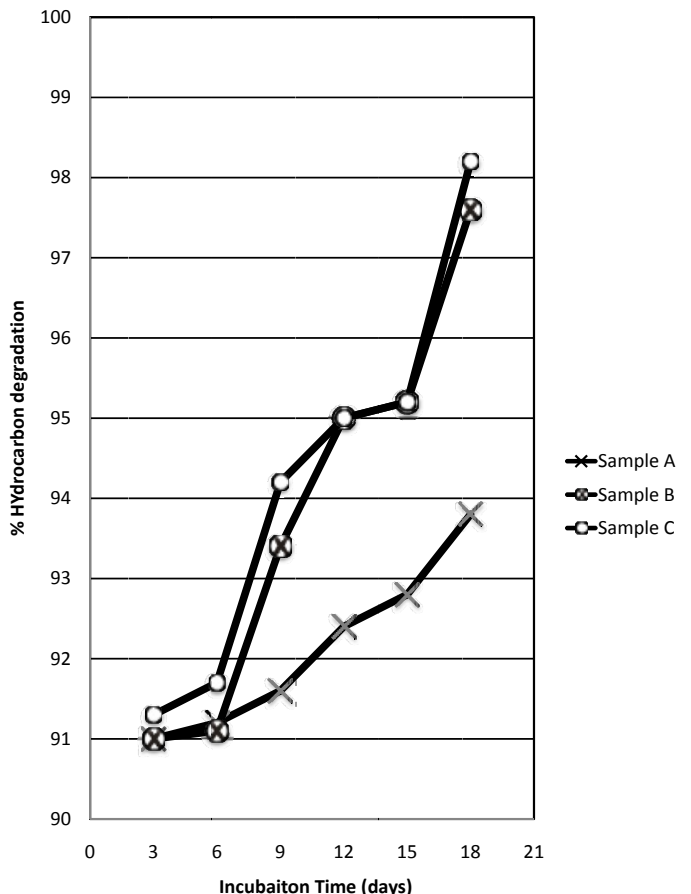

Figure 5b: \% Degradation of Diesel using Klebsiella amended with NPK and Cow dung.

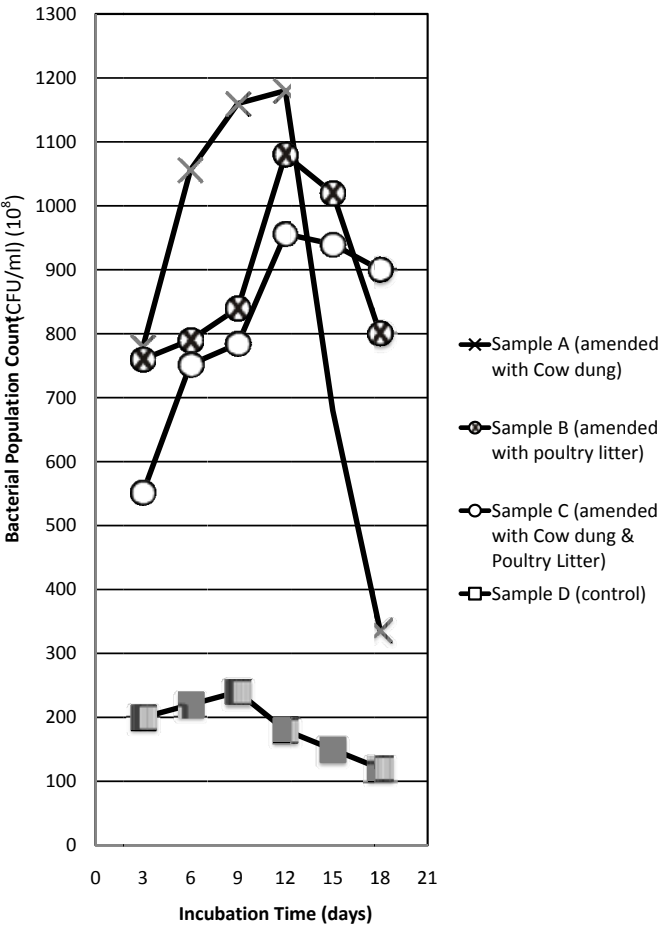

Figure 6a: Bioremedidaiton of Engine Oil contaminated using Klebsiella amended with cow dung \& poultry litter.

and $0.5 \mathrm{~g}$ of cow dung.

ii. Sample B: $0.4 \mathrm{ml}$ Klebsiella sp stock solution, $10 \mathrm{~g}$ soil sample, $50 \mathrm{ml}$ mineral salt, $1 \mathrm{ml}$ diesel and $1 \mathrm{~g}$ cow dung.

iii. Sample C: $0.4 \mathrm{ml}$ Klebsiella sp, $10 \mathrm{~g}$ soil sample, $1 \mathrm{ml}$ diesel and $0.5 \mathrm{~g}$ each of poultry litter and cow dung.

iv. Sample D (Control): contains all except cow dung and poultry litter.

6. Biodegradation of engine oil using Klebsiella $s p$ amended with cow dung and poultry litter (Figure $6 \mathrm{a} \& 6 \mathrm{~b}$ ). It consists of four (4) tests as;

i. Sample A: $0.4 \mathrm{ml}$ stock solution of Klebsiella sp, $10 \mathrm{~g}$ soil samples, $50 \mathrm{ml}$ mineral salt, $1 \mathrm{ml}$ engine oil, $1 \mathrm{~g}$ cow dung.

ii. Sample B: $0.4 \mathrm{ml}$ Klebsiella sp stock solution, $10 \mathrm{~g}$ soil sample, $50 \mathrm{ml}$ mineral salt, $1 \mathrm{ml}$ engine oil and $1 \mathrm{~g}$ poultry.

iii. Sample C: $0.4 \mathrm{ml}$ Klebsiella sp stock solution, $50 \mathrm{ml}$ mineral salt, $10 \mathrm{~g}$ soil sample, $1 \mathrm{ml}$ engine oil, $0.5 \mathrm{~g}$ cow dung, $0.5 \mathrm{~g}$ poultry litter.

iv. Sample D (Control): contains all minerals except cow dung or poultry litter.

In all for each sample analysis, six (6) tests were carried out at three (3) days interval over eighteen (18) days period. Residual hydrocarbon was determined using Spectrophotometric analysis.

Percentage hydrocarbon degradation was calculated using =

$\frac{A-B}{A} \times 100$ 
Citation: Nduka JK, Umeh LN, Okerulu IO, Umedum LN, Okoye HN (2012) Utilization of Different Microbes in Bioremediation of Hydrocarbon Contaminated Soils Stimulated With Inorganic and Organic Fertilizers. J Pet Environ Biotechnol 3:116. doi:10.4172/2157-7463.1000116

Page 6 of 9

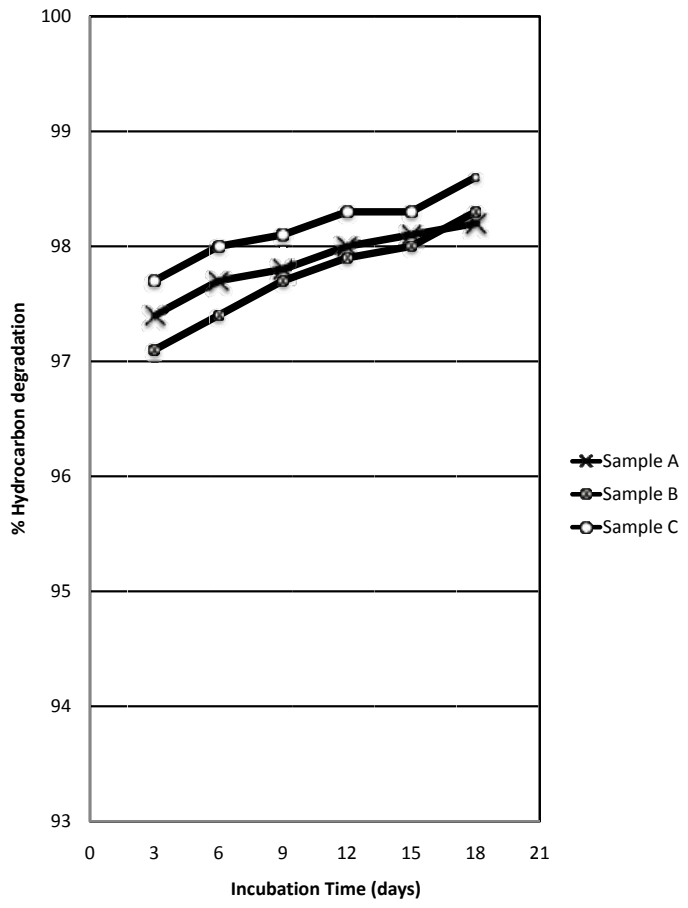

Figure 6b: \% Degradation of Engine Oil using Klebsiella amended with Cow dung \& Poultry Litter.

Where $\mathrm{A}=$ initial hydrocarbon concentration $(1 \mathrm{ml})$

$\mathrm{B}=$ Residual hydrocarbon concentration after each incubation period.

\section{Results and Discussion}

Both bacteria and fungi that are heterotrophic in nature are related to a large number of taxonomic genera which are able to utilize hydrocarbons as sources of energy and carbon for their growth [24,25]. Biotechnology of oil degradation can be divided into three (3) main groups depending on the nature of micro organisms being used:- activation of indigenous micro flora in the polluted area by addition of nutrients in the form of mineral fertilizers; addition to the polluted area of oil oxidizing micro organisms isolated from different biotopes and selected under laboratory conditions on the basis of the level of their oil oxidizing ability; and addition to the polluted area of genetically engineered micro organisms characterized by pronounced oil-oxidizing ability [26]. This study, though a preliminary one falls under the second category with an interesting discovery from Figure 1a $\& 1 \mathrm{~b}$, it can be implied that E.coli is not a very good kerosene degrader using population count and residual kerosene as indices. The organism showed an ability to utilize kerosene as a sole source of carbon and energy when stimulated with urea fertilizer. This was observed by an increase in the bacteria population count for sample B at three (3) days interval from up to fifteenth $\left(15^{\text {th }}\right)$ day of incubation while samples A and $\mathrm{C}$ showed great decrease. Samples A and C that had rapid decrease in bacteria population count had higher concentration of residual kerosene and less percentage degradation of kerosene (Figure $1 \mathrm{~b}$ and Table 1). From Figure $2 \mathrm{a} \& 2 \mathrm{~b}$, the same $E$-coli degraded engine oil when stimulated with cow dung and NPK fertilizer. There were appreciable bacterial growth, increase in percentage degradation and reduction in the residual engine oil (Table 1, Figure 2a \& 2b). In sample A containing equal NPK and cow dung, more population bacterial count and less residual engine oil was observed than in samples $B$ and $C$ (Table 1), but sample B shows that NPK is better source of food than cow dung. From Figures $3 \mathrm{a} \& 3 \mathrm{~b}$, more population count was observed in sample A with NPK, followed with sample C with mixture of NPK and urea while sample B with only Urea as the least, percentage degradation follows the same trend (Figure $3 \mathrm{~b}$ ), although all conditions had appreciable bacterial growth and reduced residual hydrocarbons (Table 1). Figure 4a \& 4b shows that NPK fertilizer stimulates higher bacterial growth for effective hydrocarbon degradation. More population count, higher percentage degradation and less residual hydrocarbon (fuel) were observed in sample A followed by sample B and less in sample C (combination of Urea and NPK). In spite of the fact that percentage of hydrocarbon degradation was the same after 18 days, in general, Proteus $s p$ proved a very good degrader of fuel (Table 1). Klebsiella species can be said to be a good degrader of diesel given the appropriate stimulation, this is provided by poultry litter and combination of cow dung and poultry litter Figure $5 a \& 5 b$ (samples A, B and C). Figure $6 a \& 6 b$ shows that cow dung assisted Klebsiella in degrading engine oil than poultry litter but both (sample A and B) were better than the combination of the two (sample C) except for the sharp decrease in population count of sample A after $15^{\text {th }}$ day of incubation. It was observed that NPK is a better source of food for the microbes; therefore high hydrocarbon degradation occurs in the presence of NPK and in the mixture of NPK and Urea (Figure 3a \& 3b). Population count increases gradually up to the $15^{\text {th }}$ day when it begins to decrease. The decrease from the fifteenth $\left(15^{\text {th }}\right)$ day may be due to secretion of secondary metabolites by the microbes which may be toxic to microbe themselves. It was also noticed from Table 1, that the residual hydrocarbon concentration decreases (increasing percentage degradation) as the population count increases: NPK stimulates the microbes to degrade hydrocarbon better as was seen in (Figure $2 \mathrm{a} \& 2 \mathrm{~b}, 3 \mathrm{a} \& 3 \mathrm{~b}$ and $4 \mathrm{a} \& 4 \mathrm{~b}$ ) as well as when in combination (Figure $2 a \& 2 b, 3 a \& 3 b$ ). Poultry litter enhances the degradation of diesel better than cow dung or the combination of both (Figure $5 \mathrm{a} \& 5 \mathrm{~b}$ ). NPK, poultry litter, cow dung or their combination stimulates greater degradation of engine oil (Figure $2 a \& 2 b, 6 a \& 6 b$ ). Generally it was also observed that Proteus, Pseudomonas, Klebsiella species are better hydrocarbon degraders than E.coli, depending on hydrocarbon and fertilizer amendment used in the experiment.

This method can be applied in water. Bacteria and other microorganisms composing the marine flora are able to feed upon wide variety of compounds found in petroleum, the oil spillages that occur in the coastal areas would persist if not for these organisms. Other microorganisms other than bacteria metabolize oil as did higher organism, example alga, Walker et al. [27], isolated an alga, prototheca zopfi which was capable of utilizing crude oil and a mixed hydrocarbon substrate and exhibited extensive degradation of $\mathrm{n}$-alkanes and isoalkanes as well as aromatic hydrocarbons.

Urea fertilizer was the best amendment for E.coli to degrade kerosene (Figures $1 \mathrm{a} \& 1 \mathrm{~b}$ ), NPK and cow dung differently aided the same E.coli in degrading engine oil (Figures 2a \& 2b). Pseudomonas and Proteus species degraded kerosene and fuel better in the presence of NPK fertilizer (Figures 3a-4a, 3b-4b), Klebsiella species degraded diesel and engine oil better when amended with poultry litter and cow dung respectively at least for the first 9 days (Figures $5 a \& 6 a, 5 b \&$ $6 b)$. Equally, good results were obtained by combining NPK and cow dung (Figure 2a), NPK and urea (fig 3a), cow dung and poultry litter (Figures $5 \mathrm{a} \& 6 \mathrm{a}$ ), with their corresponding percentage degradation (Figures 2b-6b). 
Citation: Nduka JK, Umeh LN, Okerulu IO, Umedum LN, Okoye HN (2012) Utilization of Different Microbes in Bioremediation of Hydrocarbon Contaminated Soils Stimulated With Inorganic and Organic Fertilizers. J Pet Environ Biotechnol 3:116. doi:10.4172/2157-7463.1000116

Page 7 of 9

\begin{tabular}{|c|c|c|c|c|c|c|c|}
\hline \multirow{2}{*}{ S/No } & \multirow{2}{*}{ Experiment No } & \multirow{2}{*}{ Hydrocarbon Used } & \multirow{2}{*}{ Microbe Used } & \multirow{2}{*}{$\begin{array}{l}\text { No of days of } \\
\text { Incubation }\end{array}$} & \multicolumn{3}{|c|}{ Residual hydrocarbon after incubation $(\mathrm{mg})$} \\
\hline & & & & & Sample A & Sample B & Sample C \\
\hline \multirow{6}{*}{1} & \multirow{6}{*}{1 (Figure 1) } & \multirow{6}{*}{ Kerosene } & \multirow{6}{*}{ E. Coli } & 3 & 0.066 & 0.019 & 0.058 \\
\hline & & & & 6 & 0.054 & 0.016 & 0.049 \\
\hline & & & & 9 & 0.042 & 0.015 & 0.036 \\
\hline & & & & 12 & 0.031 & 0.014 & 0.033 \\
\hline & & & & 15 & 0.029 & 0.013 & 0.029 \\
\hline & & & & 18 & 0.024 & 0.012 & 0.026 \\
\hline \multirow{6}{*}{2} & \multirow{6}{*}{2 (Figure 2) } & \multirow{6}{*}{ Engine oil } & \multirow{6}{*}{ E. Coli } & 3 & 0.035 & 0.037 & 0.038 \\
\hline & & & & 6 & 0.033 & 0.035 & 0.036 \\
\hline & & & & 9 & 0.032 & 0.034 & 0.032 \\
\hline & & & & 12 & 0.026 & 0.022 & 0.020 \\
\hline & & & & 15 & 0.019 & 0.014 & 0.018 \\
\hline & & & & 18 & 0.017 & 0.008 & 0.011 \\
\hline \multirow{6}{*}{3} & \multirow{6}{*}{3 (Figure 3 ) } & \multirow{6}{*}{ Kerosene } & \multirow{6}{*}{ Pseudomonas } & 3 & 0.035 & 0.038 & 0.034 \\
\hline & & & & 6 & 0.034 & 0.036 & 0.034 \\
\hline & & & & 9 & 0.024 & 0.026 & 0.025 \\
\hline & & & & 12 & 0.020 & 0.024 & 0.022 \\
\hline & & & & 15 & 0.019 & 0.020 & 0.019 \\
\hline & & & & 18 & 0.012 & 0.019 & 0.018 \\
\hline \multirow{6}{*}{4} & \multirow{6}{*}{3 (Figure 4) } & \multirow{6}{*}{ Fuel } & \multirow{6}{*}{ Proteus } & 3 & 0.030 & 0.035 & 0.045 \\
\hline & & & & 6 & 0.027 & 0.034 & 0.039 \\
\hline & & & & 9 & 0.022 & 0.031 & 0.025 \\
\hline & & & & 12 & 0.021 & 0.030 & 0.019 \\
\hline & & & & 15 & 0.019 & 0.016 & 0.015 \\
\hline & & & & 18 & 0.012 & 0.014 & 0.013 \\
\hline \multirow{6}{*}{5} & \multirow{6}{*}{3 (Figure 5) } & \multirow{6}{*}{ Diesel } & \multirow{6}{*}{ Klebsiella } & 3 & 0.090 & 0.090 & 0.087 \\
\hline & & & & 6 & 0.088 & 0.089 & 0.083 \\
\hline & & & & 9 & 0.084 & 0.066 & 0.058 \\
\hline & & & & 12 & 0.076 & 0.050 & 0.050 \\
\hline & & & & 15 & 0.072 & 0.048 & 0.048 \\
\hline & & & & 18 & 0.062 & 0.024 & 0.018 \\
\hline & & & & 3 & 0.026 & 0.029 & 0.023 \\
\hline & & & & 6 & 0.023 & 0.026 & 0.020 \\
\hline 6 & 3 (Fiaurn 6) & Engino Oil & Klohcis/la & 9 & 0.022 & 0.023 & 0.019 \\
\hline 6 & 3 (Figure 6) & Engine Ull & Klebsiella & 12 & 0.020 & 0.021 & 0.017 \\
\hline & & & & 15 & 0.019 & 0.020 & 0.017 \\
\hline & & & & 18 & 0.018 & 0.017 & 0.014 \\
\hline
\end{tabular}

Table 1: Residual Concentration of Hydro carbon in mg after each Incubation Period.

Inorganic/organic nutrient addition or their combination was most affective. It significantly enhanced microbial populations and hydrocarbon biodegradation rate (Figures 1a, 6a \& Figures 1b, 6b). All the microbes used can be referred to as halophiles (microorganism requiring salt for growth) as the low concentration of mineral salts aided their ability to degrade hydrocarbon. Ward and Brock [28], assumed an inverse relationship between biodegradation of petroleum hydrocarbon and salinity. A range of organic pollutants has been shown to be mineralized or transformed by microorganisms able to grow in the presence of salt $[29,30]$.

Halophilic archaea maintain an osmotic balance with the hypersaline environment (as may be seen in salt marshes and swamps of Niger delta region of Nigeria) by accumulating high salt concentration which requires salt adaptation of the intracellular enzymes, the use of micro-organisms able to degrade organic wastes in the presence of salt could prevent costly dilution to lower the salinity or the removal of salt by reverse osmosis, ion exchange or electro dialysis before biological treatment [31].

Chain length of the hydrocarbon also plays a major role in determining rate of degradation(Figures $1 \mathrm{a}-6 \mathrm{a} \& \mathrm{1b}-6 \mathrm{~b}$ ), it is noticed that the longer the carbon chain length, the better the degradation, therefore diesel/engine oil is degraded better than kerosene which is better degraded than fuel. But in all, type of microbe, hydrocarbon used and fertilizer amendment determined the bacterial population count and the percentage of hydrocarbon degraded.

In the control, it is noticed that there is initial rise in population count of the microbes due to utilization of the hydrocarbons for carbon and energy (Figures 1a $-6 a$ ), but they begin to die due to lack of fertilizer stimulation and less than $50 \%$ of the hydrocarbons were degraded in all the control experiment (Table 2). The growth of plant on the remediated soil after six (6) days of planting proves the effectiveness of the treatment. Although there is no remarkable difference in the biodegradation of hydrocarbons when stimulated with synthetic (NPK and Urea) fertilizer and natural organic (cow dung and poultry litter) fertilizer or their combination, the use of fertilizer had led to better growth of the bacteria and thereby increased the bacteria to at least three fold [32], it is better to use cow dung and poultry litter which are cost effective and more environmentally friendly. The degradation 
Citation: Nduka JK, Umeh LN, Okerulu IO, Umedum LN, Okoye HN (2012) Utilization of Different Microbes in Bioremediation of Hydrocarbon Contaminated Soils Stimulated With Inorganic and Organic Fertilizers. J Pet Environ Biotechnol 3:116. doi:10.4172/2157-7463.1000116

Page 8 of 9

\begin{tabular}{|c|c|c|c|c|c|c|}
\hline S/No & Experiment No & Hydrocarbon Used & Microbe Used & $\begin{array}{l}\text { No of days of } \\
\text { Incubation }\end{array}$ & $\begin{array}{l}\text { \% hydrocarbon } \\
\text { degradation }\end{array}$ & $\begin{array}{l}\text { Residual hydrocarbon after } \\
\text { incubations }(\mathrm{mg})\end{array}$ \\
\hline \multirow{6}{*}{1} & \multirow{6}{*}{1 (Figure 1) } & \multirow{6}{*}{ Kerosene } & \multirow{6}{*}{ E. Coli } & 3 & 28.46 & 0.715 \\
\hline & & & & 6 & 32.33 & 0.677 \\
\hline & & & & 9 & 35.26 & 0.647 \\
\hline & & & & 12 & 36.41 & 0.636 \\
\hline & & & & 15 & 38.29 & 0.617 \\
\hline & & & & 18 & 38.98 & 0.610 \\
\hline \multirow{6}{*}{2} & \multirow{6}{*}{2 (Figure 2) } & \multirow{6}{*}{ Engine oil } & \multirow{6}{*}{ E. Coli } & 3 & 35.80 & 0.642 \\
\hline & & & & 6 & 37.92 & 0.621 \\
\hline & & & & 9 & 39.41 & 0.606 \\
\hline & & & & 12 & 40.26 & 0.597 \\
\hline & & & & 15 & 42.18 & 0.578 \\
\hline & & & & 18 & 43.26 & 0.642 \\
\hline \multirow{6}{*}{3} & \multirow{6}{*}{3 (Figure 3) } & \multirow{6}{*}{ Kerosene } & \multirow{6}{*}{ Pseudomonas } & 3 & 34.27 & 0.657 \\
\hline & & & & 6 & 42.50 & 0.575 \\
\hline & & & & 9 & 43.80 & 0.562 \\
\hline & & & & 12 & 44.21 & 0.558 \\
\hline & & & & 15 & 45.80 & 0.542 \\
\hline & & & & 18 & 46.30 & 0.537 \\
\hline \multirow{6}{*}{4} & \multirow{6}{*}{3 (Figure 4) } & \multirow{6}{*}{ Fuel } & \multirow{6}{*}{ Proteus } & 3 & 30.24 & 0.698 \\
\hline & & & & 6 & 32.18 & 0.678 \\
\hline & & & & 9 & 33.80 & 0.662 \\
\hline & & & & 12 & 36.46 & 0.634 \\
\hline & & & & 15 & 38.20 & 0.618 \\
\hline & & & & 18 & 40.14 & 0.599 \\
\hline \multirow{6}{*}{5} & \multirow{6}{*}{3 (Figure 5) } & \multirow{6}{*}{ Diesel } & \multirow{6}{*}{ Klebsiella } & 3 & 35.26 & 0.647 \\
\hline & & & & 6 & 37.18 & 0.628 \\
\hline & & & & 9 & 38.30 & 0.617 \\
\hline & & & & 12 & 39.86 & 0.601 \\
\hline & & & & 15 & 42.30 & 0.577 \\
\hline & & & & 18 & 43.78 & 0.562 \\
\hline \multirow{6}{*}{6} & \multirow{6}{*}{3 (Figure 6) } & \multirow{6}{*}{ Engine Oil } & \multirow{6}{*}{ Klebsiella } & 3 & 34.18 & 0.658 \\
\hline & & & & 6 & 35.24 & 0.648 \\
\hline & & & & 9 & 36.86 & 0.631 \\
\hline & & & & 12 & 38.40 & 0.616 \\
\hline & & & & 15 & 41.28 & 0.587 \\
\hline & & & & 18 & 43.60 & 0.564 \\
\hline
\end{tabular}

Table 2: The results of the control experiment showing the percentage hydrocarbon degradation and amount of residual hydrocarbon after incubation.

is preceded by an initial uptake step considered to involve physical adhesion of the oil droplets to the cell or enhanced by solubilization in the aqueous phase [33]. The low solubility of many hydrocarbons facilitates the separation of the aqueous and hydrocarbon phases following the fermentation and enhancing product recovery by partitioning the water soluble and hydrocarbon-soluble products. The next step occurs in the membrane, where the hydrocarbons dissolve in the lipophilic region and the results of enzyme-mediated reactions are usually carbon dioxide, water and other intermediate by -products [34]. The performance of these hydrocarbon degraders is used in remediation, therefore micro organism's ability to degrade hydrocarbon helps a polluted environment to regain its natural characteristics and restoration of normalcy in our environment. We therefore conclude that, though our work is a laboratory study, it can be applied on a large scale to remediate soils contaminated with crude oil or its fractions.

\section{References}

1. Rahman KS, Rahman TJ, Kourkoutas Y, Petsas I, Marchant R, et al. (2003) Enhanced bioremediation of $n$-alkane in petroleum sludge using bacterial consortium amended with rhamnolipid and micronutrients. Bioresour Technol 90: 159-168.
2. Trabalka JR, Retchle DE (1986) The changing carbon cycles: A global Analysis Springe Berlin.

3. Rahman KSM, Banat IM, Thahira J, Thayamanavan T, Lakshmanaerumalsamy $\mathrm{P}$ (2002) Bioremediation of gasoline contaminated soil by a bacterial consortium amended with poultry litter, coir pith and rhamnolipid biosurfactant. Bioresour Technol 81: 25-32.

4. Martello A (1991) Bioremediation: cleaning up with Biology and Technology 5: 7.

5. Bonaventure C, Jonson FM (1997) Healthy Environments for Healthy people: Bioremediation today and tomorrow. Environ Health Perspect 1: 5-20.

6. Young PY, Johnson RL, XU JG (1996) Biodegradation of Petroleum hydrocarbons in soil as affected by heating and forced aeration. J Environ Qual 26: 1511-1516

7. Descai JD, Banat IM (1997) Microbial production of surfactants and their commercial potential. Microbiol Mol Biol Rev 61: 47-64.

8. Das N, Chandran P (2011) Microbial degradation of petroleum hydrocarbon contaminants; An overview. Biotechnol Res Int 2011: 941810

9. Fought JM, Westlate, DWS (1987) Biodegradation of hydrocarbons in fresh water. Pergamon Press Co. New York: 217-230.

10. Amund OO (1984) Observation on the degradation of crude mineral oil by estuarine Microbial community. Nig J Microbial 4: 134-143. 
Citation: Nduka JK, Umeh LN, Okerulu IO, Umedum LN, Okoye HN (2012) Utilization of Different Microbes in Bioremediation of Hydrocarbon Contaminated Soils Stimulated With Inorganic and Organic Fertilizers. J Pet Environ Biotechnol 3:116. doi:10.4172/2157-7463.1000116

11. Amadi A (1988) An Assessment of the performance of some petroleum degrading microorganisms. J Appl Bacterilo 4: 61-67.

12. Frankenberger WT (1988) Use of Urea as a Nitrogen fertilizer in Bio-reclamation of petroleum hydrocarbons in soil. Bull Environ Contam Toxicol 40: 66-68.

13. Ngobiri CN, Ayuk AA, Anunuso C I (2007) Differential degradation of hydrocarbon fraction during bioremediation of crude oil polluted sites in the Niger- delta area. J Chem Soc Nigeria 32: 151-158.

14. Potter CL, Glasser JA, Herman R, Dosani MA (1999) Remediation of contaminated East River sediment by composting technology. In; Leeson A, Alleman BC (eds).Bioremediation technologies for polycyclic aromatic hydrocarbon compounds. The fifth international in-situ and On-site bioremediation symposium. Battelle press: Columbus: 31-36.

15. Manios T, Manniadakis K, Kalogeraki M, Mari E, Stratakis E, et al. (2006) Efforts to explain and control the prolonged thermophilic period in two-phase olive oil mill sludge composting. Biodegradation 17: 285-292.

16. Marin JA, Moremo JL, Hemandez T, Garcia C (2006) Bioremediation by composting of heavy oil refinery sludge in semiarid conditions. Biodegradation 17: $251-261$

17. Atagana HI, Haynes RJ, Wallis FM (2003) Co-composting of soil heavily contaminated with creosote with cattle manure and vegetable waste for the bioremediation of creosote-contaminated Soil. An International Journal 12: 885-899.

18. Atagana $\mathrm{HI}$ (2008) Compost bioremediation of hydrocarbon contaminated soil inoculated with organic manure. African Journal of Biotechnology 7: 15161525

19. Okolo JC, Amadi EN, Odu CTI (2005) Effects of soil treatments containing poultry manure on crued oil degradation in a sandy loam soil. Applied and Environmental Research 3: 47-53.

20. Atagana $\mathrm{HI}$ (2004) Co composting of $\mathrm{PAH}$-contaminated soil with poultry manure. Lett Appl Microbiol 39:163-168.

21. Pramer D, Bartha R (1972) Preparation and processing of soil samples for biodegradation studies. Environmental Letters 2: 217-224.

22. Watwood ME, White CS, Dahm CN (1991) Methodological modifications for accurate and efficient determination of contaminant biodegradation in unsaturated calcareous soils. Appl Environ Microbiol 57: 717-720.

23. Okpokwasili GC, Okerie BB (1988) Biodeterioration potential of microorganism Tribol Int Sweden: 215-220.

24. Atlas RM (1984) Microbiology. Fundamentals and Applications. New York Macmillan Publishing Company.

25. Pritchard PH, Mueller JG, Rogers JC, Kremer FV, Glaser JA (1992) Oil Spill bioremediation: Experiences, Lessons and Results from the Exxon valdez oil spill in Alaska. Biodegradation 3: 315-335

26. Groudeva VI (1997) Application of Bioremediation Technologies for cleaning of crude oil polluted soils in Bulgaria. Department of General and Industrial Microbiology, Faculty of Biology; University of Sofiabul. Dragon Tzankov 8 : 1421.

27. Walker JD, Colwell RR, Vaituzis Z, Meyer SA (1975) Petroleum degrading achlorophyllous alga prototheca zopfi. Nature 254: 423-424.

28. Ward DM, Brock TD (1978) Hydrocarbon degradation in hypersaline environments. Appl Environ Microbiol 35: 353-359.

29. Oren A, Gurevich P, Azachi M, Hents YC (1992) Microbial degradation of pollutants at high salt concentrations. Biodegradation 3: 387-398.

30. Margesin R, Schinner F (2001) Potential of halotolerant and halophilic microorganisms for biotechnology. Extremophiles 5: 73-83.

31. Margesin R, Schinner F (2001) Biodegradation and bioremediation of hydrocarbons in extreme environments. Appl Microbiol Biotechnol 56: 650 663.

32. Eugene WN, Roberts CE (1998) Microbiology: Human Perspective. Mc-GrawHill London.

33. Abbott BJ, Gledhill WE (1971) The extracellular accumulation of metabolic products by hydrocarbon degrading microorganisms. Adv Appl Microbiol 14 249-388.

34. Kaytinger HW (1993) Advances in microbial engineering. John Wiley, New York, USA. 